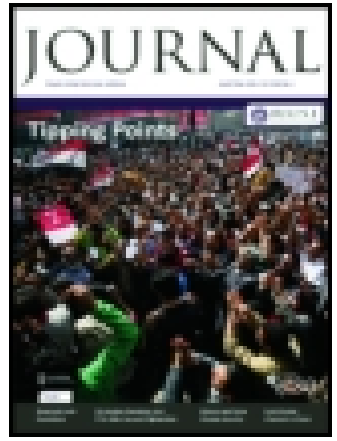

Royal United Services Institution. Journal

\title{
On the Sanitary Condition of the British Army; and Especially on the Want of Space in Barracks
}

\section{William Augustus Guy Esq., M.B. Cantab}

To cite this article: William Augustus Guy Esq., M.B. Cantab (1858) On the Sanitary Condition of the British Army; and Especially on the Want of Space in Barracks, Royal United Services Institution. Journal, 2:5, 1-32, DOI: 10.1080/03071845809415893

To link to this article: http://dx.doi.org/10.1080/03071845809415893

曲 Published online: 11 Sep 2009.

Submit your article to this journal $₫$

Џll Article views: 4

Q View related articles $₫$ 


\section{dyoumal}

\section{OF TIE

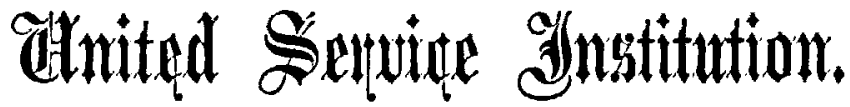

\begin{tabular}{lll}
\hline VoL. II. & 1858. & No. V. \\
\hline
\end{tabular}

\section{LEC'TURS.}

Tuesday, 23rd March, 1858.

The Rignt Hoxocrable SIDNEY IIERBERT, M.P., in the Chair.

ON THE SANITARY CONDITION OF THE BRITISH ARALY; AND ESPECIALLY ON THE WANT OF SPACE IN BARR ACKS.*

13y Willay Acaustus GuY, Esq., M.B. Cantab.; Fellow of the Royal College of Physicians; Professor of Forensic Medicine, King's College, London; Physician to King's College Hospital; and one of the Honorary Secretaries of the Statistical Society.

I have sought this opportunity of addressing ycu, because I wish to acquit myself of some part of that great debt of gratitude which, in conmon with all who devote themselves to the cultivation of the arts of peace, and who are not wholly insensible to its blessings, I

* In consequence of the interest attached to the subject of Barrack accom. modation, and its bearing upon the Health of the Soldier, it has been thought expedient to print the above Lecture out of its regular course, in order that it may the sooner be brought before the public.

VOL. II. 
feel that $I$ owe to the brave men who fight our battles by land and by sea. I would fain render some slight service to those gallant men. But my debt to the uavy must remain unpaid, because, as I need scarcely tell you, for the last three quarters of a century, since the memorable voyages of Captain Cook, the condition of the sailor in all that relates to the preservation of his health, and the enlargement of his comforts, has been one of progressive improvement, so that it is now scarcely possible for a civilian, like mysclf, to suggest nnything that will conduce to his advantage. Not so, howerer, with the soldier: for I will undertake to say that there is no man, however ignorant he may be of sanitary science, however little knowledge he may have of the causes which tend to preserve health, or to destroy it; there is no one, how narrow socver his notions may be of the comforts which men in a humble sphere of life ought to enjoy, who could not, on the most cursory inspection of our barracks, and the most superficial knowledge of the routine of a soldier's duties, point out many things that would conduce greatly to his advantage, and which, if we would not altogether forfeit our old reputation for humanity, justice, sound sense, and true economy, ought, without one moment's delay, to be carried into effect. I do not therefore think that I lay myself open to the charge of presumption in coming before you, as a civilian, to talk to you, soldiers, upon this grave question, and to discuss the contents of the valuable Report which lies upon your table.

This Report, as most of you probably are aware, is entitled "The Report of the Commissioners appointed to inquire into the Regulations affecting the Sanitary Condition of the Army, the Organization of Military Hospitals, and the Treatment of the Sick and Wounded." It is a bulky rolume, and contains, in addition to the usual summary and recommendation of the Commissioners, a great mass of evidence, and a very valuable $A_{\text {ppendix. }}$ The Report is signed by the Right Honourable Gentleman now in the Chair, who has shown himself a true and tried soldier's friend, and who, I hope and believe, will maintain his character to the eud of his days. This Report is also signed by several gentlemen, among whom are some of my personal friends. They are all of them men above suspicion, and quite incapable of intentionally misrepresenting or exaggerating the facts that were brought under their notice. 
I may also speak in terms of similar commendation of the witnesses who hare given their evidence before this Conmission, among whom I may also mention that there are several of my personal friends; and I may undertake to say of them that, throughout the length and breadth of Europe, there are not to be found men, in their peculiar line, who could be brought into comparison with them. I speak of Sir Alexander Tulloch, Dr. William Farr, Mr. Neisoni, Dr. Balfour, and my old friend Dr. Sutherland, with whom I was associated fifteeu years ago in sanitary movements and agitations. They are quite incapable of representing anything before this Commission which they did not believe to be truethey are quite incapable of exaggerating the evils under which the soldier is represented to be labouring.

I may also add, that there will be found in the Appendix to this Report a very valuable paper, consisting of answers to written questions addressed to her by the Commission from the pen of that gentle lady whose presence at the bedside of the sick soldier in the hospitals of the East was felt to be as rays of sunshine in a dark place-I mean Miss Nightingale. And it must be a great satisfaction to the soldier to know that, though she no longer ministers in person to his wants, she is now as deeply interested as crer in his behalf, and is labouring with all the energy, zeal, and talent of a man, and all the gentleness, tenderness, and constancy of a woman, to promote to the utmost possible extent the welfare of the brave men to whose cause she is so warmly attached.

Now, this Report, to which I have thus sursorily alluded, brings into bold relief one great fuct-one distressing and disfraceful fact - that the mortality of our soldiers, especially of the infantry, and more especially of the Foot Guards, is very much greater than that of any class of the civil population, with whom it seemed to be reasonable, and natural, and fair, to compare them. And when you reflect that the army is recruited from a population some of whom are conscious of defects that prevent them from ever offering themselves as soldiers, and others are rejected in large numbers when they do offer; when you bear in mind, too, that great numbers of soldiers are sent back, as invalids or pensioners, to the population from which they were drawn, to be reckoned when they die, not as soldiers but as civilians, so as to swell the proper rate of 
mortality of the civil population, and to diminish, in like proportion, that of the Army, you will be able to appreciate the gravity of this statement.

But this is no new fact; for at page 250 of the second volume of he Journal of the Statistical Society, published in 1839 , there is a paper from the pen of Mr. I. W. C. Lever, in which he contrasts the facts contained in the then recent Report of Sir Alexander Tullocl, on the mortality prevailing among our troops during the seven years ending 1536 , with similar facts relating to the civil population.

In that publication, the fuct that British soldiers, and the infantry more especially, are subject to a very great mortality, as compared with civilians of the same ages, was clearly set forth. I have prepared a table embodying these facts; but, as I shall not have time to comment upon it at any length, $I$ must be satisfied with clirecting your attention to it.

Mortalitr in the Arar, 1830-1836.

Annual Deaths in 10,000 living.

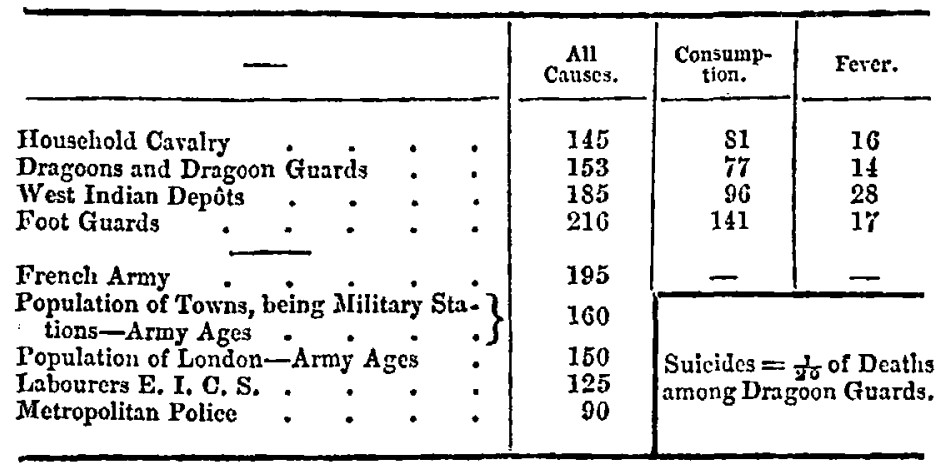

You will find that the facts cmbodied in this Table, relating to an earlier period of the history of our army, are in harmony with the statements made in this Report of Mr. Sidney Herbert's Conmission, though the rate of mortality is higher at the carlice date. But I must invite your attention to one melancholy fact stated in the 'lable, that, among our Dragoon Guards, no less than one-twentieth of all the deaths was attributed to suicide.

I say, then, that this fact of the great mortality of the British soldier is no new fact. To our disgrace be it spoken, it was known 
twenty years ago; and eleven years ago (in the spring of 1847) another fact was stated in the House of Commons in reference to our metropolitnn barracks, which I think you will agree with me is not unlikely to bear to this high mortality of the soldier the relation of cause and effect. Sir. De Lacy Evans told the Honse that, in the metropolitan barracks, a room 32 feet long and 20 broad was all the convenience then afforded for the eating, sleeping, and general living of twenty men and non-commissioned officers, some two or three of the men being in all probability married. Such a room would probably not afford to each inmate more than from 250 to 300 cubic feet of air, or from a fourth to a third of the prison allowance. On the same occasion Colonel Lindsay stated that in one case he had found an allowance of 357 cubic feet, and in another of 330 cubic feet.* Therefore, neither the fact that the life of the British soldier is shortened, nor one of the leading causes to which I shall have occasion to attribute that curtailment of his life, are new to us. We ought lonr since not only to hare known these facts, but we ought to lave paid more attenion to them.

The precise facts relating to the present mortality of the soldier, as compared with the mortality of civilians, are embodied in an intelligible form in the Table before you.

De.atis per 10,000 per Annus at tine Soldiens' Ages.

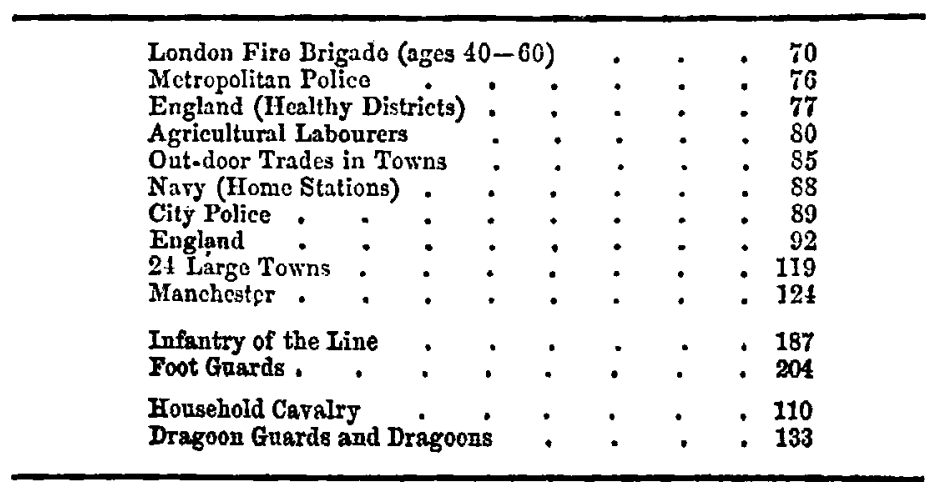

* I talse this opportunity of stating that some passages in this Lecture are but slightly altered from similar passages in my article on "The Mortality in the Army," published in Fraser's Magazine for April. Having stated this fact, I do not deen it necessary to distinguish the passages in question by marks of quotation, 
The facts, with one exception, are taken from the leport of the Commissioners. The exceptional case stands at the head of the table, and relates to an important class of men, of whom I shall presently give you some account-I mean the London Fire Brigade. The figures which exhibit the very favourable rate of mortality of this class are followed by those which display the mortality in several distinct bodies of civilians, namely, the Metropolitan Police, the inhabitants of the healthy districts of England, agricultural labourers, men following out-door trades in towns, the Nary on home stations, the City Police, the inhabitants of England and Wales, of twenty-four large towns, and of Mauchester; and, by way of contrast, the mortality of the Infantry of the Line, of the Foot Guards, of the Household Cavalry, and of the Dragoon Guards and Dragoons. The civilians thus compared with our soldiers are, in all cases, males of the same ages with the soldiers themselves, with the exception of the men of the Fire Brigade, whose ages range from 20 to 60 . 'These men of the Fire Brigade, or Loudon Fire Engine Establishment, occupy the most favourable position in the table. They are subject to an annual mortality of only 70 in 10,000, whereas the Foot Guards suffer a mortality of 204 in 10,000 , or very nearly three times as many.

Now, this is the class of men of whom $I$ said just now that $I$ would give you some account. I am indebted for the particulars of their occupation and consequent mortality to Mr. Cliarles Frederick Browne, the surgeon to the force; and I am happy to see a gentleman here this afternoon (Mr. Braidwood, the Superintendent) who can confirm the statements I am about to make.

The ages of the firemen range from twenty to sixty and upwards; and there is one man now in the service in his 70th year, quite able to take his turn of duty with the rest. The men are carefully selected, full three-fourths of them having been man-of-war's men. The duties they have to perform are by no means light; for each man, on the average, has been on duty at the stations, or on the watch on premises damaged by fire, three days and three nights, of twelve hours each, in every week of the past year. This is exclusive of attendance to clenn the cngines and tools, and keep the hose in order, and of a sort of engine-drill for the younger men twice n-week. The men have also to attend and work at fires, where they 
are in the midst of intense lieat, stean, and smoke, saturated with water, and obliged to stand in elevated situations exposed to severe and cutting winds, so that the men are often seen in winter literally encrusted with ice. They are sometimes called out by fires, or alarms of fire, as many as four times in a vight. But, notwithstanding this hard duty and cxtreme of exposure, the rate of mortality among the men is highly favourable. For the first thirteen years of the establishment, the deaths were at the rate of 96 per 10,000; while for the last twelve years they have fallen to 70 per 10,000. Both these calculations include deaths by accident, which, in spite of the perilous nature of the employment, have not exceeded 44 in 10,000 in the whole period of twenty-five years. The higher mortality of the carly peitod is attributed, and probably with justice, to less careful selection; but the moderate rate prevailing throughout the whole period of twenty-five years is evidently to be attributed to the unusual care and attention bestowed on the comforts and health of the men, who live either at the stations or in houses provided by the establishment, and subject to careful inspection. The management is in the lands of a Committec, appointed by the several Fire Assurance offices, who pay the men liberally, give them plenty of warm and comfortable clothing, instruet the Medical Oficer and Superintendent to look narrowly to the healthy state of the stations and the other residences of the men, and act with promptitude and liberality on any suggestions which these efficient officers may please to make. This, I believe, is a fair and accurate account of this very healthy class of men.

Here, then, we have a case of night-work and exposure to weather certainly far exceeding in severity the night duty which the foot soldier has to perform; for I understand that the soldier is on guard only every fourth or fifth night. Yet this night-work, and this exposure to weather, being accompanied, in the case of the Fire Brigade, by the most scrupulous care of the health and comforts of the men, is compatible with the very favourable rate of mortality shown in the Table. May not the unfivourable death-rate of 204 in 10,000 , prevailing among the Foot Guards, be partly accounted for by the substitution of carelessness for care?

I infer, therefore, that night-work and exposure to the weather 
do not of themselves occasion the great mortality of the Foot Guards. $I$ infer that a man may have severe night-duty and much exposure to weather, and yet be long-lived; and this inference is confirmed and strengthened by the favourable rate of mortality prevailing among the Metropolitan and City Police, when compared with the Guards or with the Infuntry of the Line. The police are much more exposed to the weather, and have much more nightwork, and yet their rate of mortality is far below that of the foot soldier.

Let us next take the case of the sailor. IHe, too, has a good deal of exposure, and is subject at night to great over-crowding. His diet is also monotonous; and sometimes insufficient in quantity and defective in quality. But the sailor, as compared with the soldier, has a farourable rate of mortality, bccause, in common with the agricultural labourer, the unwholesome influences to which he is exposed are countericted by strong and varied exercise in the pure open air.

I will next ask your attention to the class of men I have just mentioned-the agricultural labourers. Their rate of mortality also is given in the Table. Agricultural labourers are a very long-lived class of men. There is no large class of the community that lives so long. And yet these men attain to this longevity, in spite of grent exposture to the wenther, in spite of great overcrowding in their sleeping places at night, in spite of unwholesome dwellings, in spite of a monotonous and scanty diet and very insufficient clothing: in defiance, as it were, of screral of those evils which are supposed to attach to the condition of the soldicr, and to account for his high mortality and short life. I conclude, therefore, that a man may be much exposed to the wenther, that he may be greatly overerowded at night, that he may be ill-clothed and badly fed, and yet, in spite of these unwholesome circumstances, if he have only hard daily labour in the pure open air, he may enjoy good health and attain to long life. The hard daily labour in the open air prores his salvation.

Let us now turn from long-lived men to short-lived men: from men having a favourable rate of mortality, though exposed to the action of certain unwholesome influences, to which, in common with 
the soldier, they are subject, to men having an unfavourable rate of mortality, due to causes which nuy also be presumed to contribute to shorten the soldier's life. The class to which I shall first invite your attention is the English aristocracy. I am able to compare their expectation of life with that of the agricultural labourer; and I find that, while the agricultural labourer at thirty years of age has an expectation of forty years and a half, the English aristocracy has an expectation of only thirty-one years. So that betreen the agricultural labourer, with all his privations and disadrantages, and the English aristocracy, having every comfort and luxury which wealth can purchase, there is a difference as against the aristocracy of nine years and a half. Now I want to draw your special attention to this favoured class, and the circumstances under which they are placed. At first sight, the position of the aristocracy would seem a very enviable one. They are able to guarantee themselves against all the causes which undermine the health and destroy the lives of the poor; but hereditary wealth, whether in the hands of men born in the ranks of the aristocracy or out of them, has this serious drawback, that it creates a great difficulty in finding a suitable, active, vigorous, exciting, interesting employment. Its possessor, therefore, naturally falls into idleness and dissipation, and this, with luxurious living, inevitably shortens his days. This is a very important fact, because it bears upon the mortality of the soldier, and illustrates some of the evils of his condition.

My object in bringing this fact thus prominently forward will at once appear, if I read to you a statement made by Coloncl Lindsay in reference to the want of interest which the soldier has in his occupation, and the consequent temptations into which Ihe falls - temptations allied to those that beset the path of the aristocracy, though, as. I need scarcely tell you, divested of the element of luxury, of which the soldier has little enough. Colonel Lindsay tells us that the Foot Guards get up at six o'clock, make their beds, clean their things, and get their breakfasts at seven; that they turn out at half-past seven or eight for a drill; but that, if it be guard day, there is no drill, except for defaulters. The men for duty are paraded at ten o'clock, and that finishes the day's drill altogether. There is evening parade, which takes 
half an hour; and then the soldicr's time is his own till tatoo, which is at nine in winter and at ten in summer. This is the day of a soldier not on guard, or not belonging to a company out for Minie practice. Now as to the consequences of this idle and lounging life: "Perhaps," says Colonel Lindsay, "no living individual suffers more than he from ennui. He has no employment save his drill and his duties. These are of a most monotonous and uninteresting description, so much so that you cannot increase their amount without wearying and disgusting him. All he has to do is under restraint; he is not like a working man or an artism. $\Lambda$ working man digs, and his mind is his own; an artisan is interested in the work on which he is engaged; but a soldier has to give you all his attention, and he has nothing to show for the work done."

Here then we have a graphic description of a man handed over by our military authorities for a prey to listlessness, idleness, and dissipation.

I think, therefore, that, setting luxury aside, in which certainly the foot soldier has no means of indulging, he is subject to the same evils which beset the aristocracy of this and all other countries. If our own aristocracy suffer less from these causes than the aristocracy of other countries, that happy result is due to that love of cnterprise, that fondness for work for work's sake, which seems born and bred in Englishmen of all classes from the highest to the lowest. This it is that saves the aristocracy of England from that extreme of degeneracy into which so many other privileged classses in all ages of the world have fallen.

There are still one or two other classes to which I must ask your attention, in order that $I$ may explain my own views of the causes of the excessive mortality to which the soldier is subject. One of the classes to which I allude consists of men who work in-doors with a great deficiency of exercise, at they same time that they inhale a close, heated, and impure atmosphere. This is the case of tailors, and of compositors in printing-offices, whose health is destroyed, and their lives greatly curtailed, by these causes. It is the case also of clerks, though they suffer more from want of exercise than from want of air. I might prove my position by figures; but I prefer stating, in general terms, that there is no doubt whatever that 
the lives of men who are thus employed are shortened by confinement and insufficient exercise. Another class of men subject to a high rate of mortality from cnuses that affect the soldier consigts of those who indulge in intemperance. The brewers' draymen and licensed victuallers aro well known to be exposed to this temptation, and are equally well known as very short-lived men. Thus, if we compare the brewers' draymen with the whole body of labourers working out of doors, among whom, of coursc, there are many intemperate men, we find the draymen s lives so curtailed by this baneful habit that at thirty-five years of age their mortality is double that of the labourers. Similar comparisons between licensed victuallers and the whole body of tradesmen, and between potboys and footmen, give the same general result.

I think that I have now sufficiently prepared you for the study of a tabular comparison, in which $I$ have arranged in one column some of those causes that are usually alleged as shortening human life, and which are also believed to injuriously affect the life of the soldier. The rest of the Table consists of cight columns, four of which have black and four red headings. The first four (those with black headings) are instances of favourable durations of life; and the last four (those with red hendings) are instances of unfavourable durations of life.* The stars indicate the presence of the several causes of disense in the classes at the head of the columns.

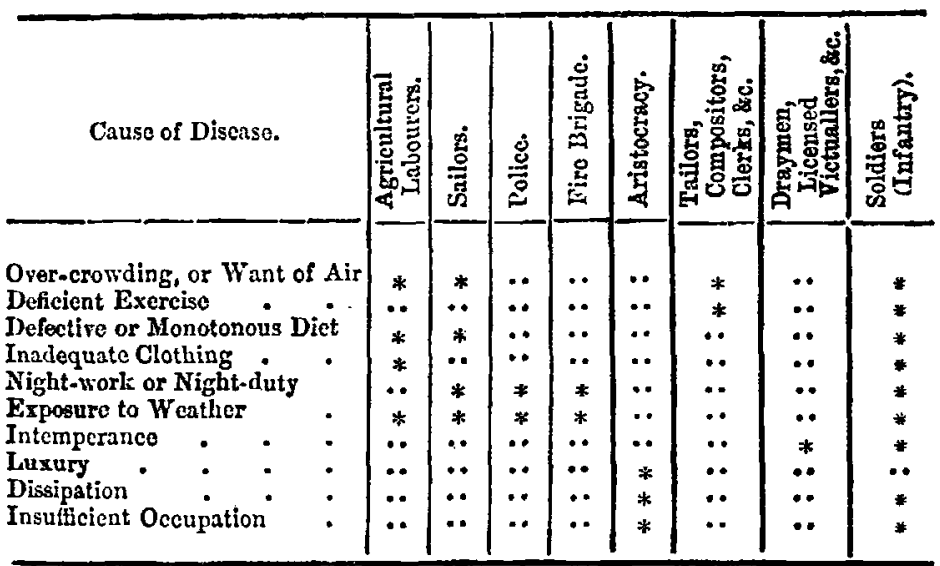

* In the annexed Table the tro scts of columns are distinguished by a difference of type. 
Let us take the severil classes one by one, and sce what lessons we can learn from them. First comes that long-lived class the agricultural labourers. The agricultural labourer, as I have said, is subject to overcrowling; he lias $\pi$ defective, scanty, and monotonous diet; his clothing is not of the best; and he suffers much from exposure to the weather. Take next the sailor. He is over-crowded in his berth at night; his diet is not varied, and in long voyages is apt to be defective; he has a good deal of nightduty, and is much exposed to the weather: still, he does not die off as the soldier does. 'The police come next in order. They have night-duty, with great exposure to weather; and so have the Fire Brigade, whose case I have brought specially under your notice,and yet they, too, are not short-lived. The men of the Fire Brigade are very much the reverse.

We now come to the four short-lived classes. We will begin with the aristocracy, whom $I$ have taken the liberty of representing as liable to fall into the twin vices of idleness and dissipation. I speak of them as a class, and of their habits of life, as a rule to which $I$ know that there are many exceptions. But as a class they have not sufficient employment to maintain them in health and vigour, and they are short-lived. My next unhealthy class consists of such men as. clerks, compositors, and tailors. They work in close and crowded rooms, and have little or no exercise - and they, too, are short-lived. Then comes the class consisting of such men as are tempted by the very nature of their occupation to indulge in spirituous liquors to excess-the class to which belong brewers' draymen and licensed victuallers. They are intemperate; and they, too, are short-lived. The unfortunate soldier comes last of all, with a star against every cause of discase but one-luxury. It is alleged, by those who are now engaged in finding out the causes of his excessive mortality, that he is over-crowded; that he slecps in a close, confined, and foctid atmosphere; that he has not such exercise as is calculated fully and freely to develop his frame; that he has a defective and monotonous diet; that his clothing does not afford adequate protection from the weather, especially when he is on night-duty; that he has this night-duty to perform under very unfavourable circum- 
stances; that he is given to intempernuce; that he is extremely dissipated; and that his occupation is insufficient. Here, then, you lave the shortest-lived class of all; and you have all these causes alleged, in explanation, some by one person and some by another, but all of then by persons who have thought upon the subject, and whose opinions arc entitled to respect.

From this comparison of soldier with civilian, I now pass to a comparison of soldier with soldier. At the foot of the Table (at p.5) you have the mortality of the Infantry of the Line and Foot Guards compared with that of the Ilousehold Cavalry and of the Dragoons and Dragoon Guards. You see that the mortality of the Infantry of the Line and Foot Guards is much more considerable than that of the Household Cavalry, or than that of the Dragoons and Dragoon Guards. Without entering into the more minute differences existing between the Cavalry and Infmitry, in regard to the amount of pay, the class from which the men are taken, the degree of care with which they are enlisted, and minor matters of that sort, I will go at once to the broad differences between them. I know of two such differences. The one is that the Cavalry soldier is a soldier and something more. He is a soldier and a groom: and every one who knows what the work of a groom is, knows that it requires a good deal of excrtion of the whole body, not simply the contracted and constrained movements of the arms and legs, which make the foot soldicr on drill look so much like an automaton, but vigorous movements of the whole frnme-good strong developing exercise of the chest and body. The other difference is that the Cavalry have more space by one-fourth or onefifth than the Foot Guards.* These two advantages, then-vigorous, varied, and wholesome exercise, and greater space in barrackswill go far to explain the very different rates of mortality prevailing among the Cavalry and Infantry.

So much, then, for the mortality of soldiers as compared with the mortality of civilians of the sane ages; and so much for the mortality of the Infantry as compared with that of the Cavalry. I have now to speak of the diseases which destroy the soldier's life, There are two classes of disease which are the special foes of the

* See Tables ii. iii. and ro, in the Appendix. 
soldier, and particularly of the Infantry soldier: mamely epidemic maladies, of which ferer is the chief; and diseases of the chest, of which consumption is the most fatal.

One of the great characteristics of fever is that it is a disease of crowds and of crowded places;-of crowded prisons, crowded workhouses, crowded ships, crowded hospitals, crowded camps, crowded barracks. If you confine men in a narrow space, fever will certainly break out among them sooner or later; and it is in such places that it spreads most rapidly from person to person, when it happens to be introduced from without.

Cholera, again, is one of those diseases which finds out over crowded and otherwise unwholesome places. Accordingly, it found out our barracks in 1849; and we learn from the Report that in some of our barracks it destroyed from twice to more than five times as many soldiers as it did civilians in the surrounding districts. We are told that, while the civil population of East London and Whitechapel lost 54, the soldiers in the Tower lost 100, in 10,000; that, while the civil population of St. Pancras lost 22 in 10,000, the soldiers in Regent's Park perished at the rate of 104 in 10,000 ; and that, while the ciril population of Kensington lost 33 in 10,000, the mortality among the soldiers at Knightsbridge was no less than 175 in 10,000 .

The Table, compiled from the paper in the Journal of the Statistical Society to which I have already referred, shows that the mortality from consumption in the army twenty years ago was very considerable. In the Household Cavalry it was 81 , in the Dragoons and Dragoon Guards 77, in the West Inclia depôts 96, but in the Foot Guards it was 141 in 10,000. That this sad state of things, though somewhat improved since that date, is not yet remedied, the following extract from the Report of the Com. missioners will show. Diseases of the lungs, which in the civil population of large towns cause 58 deaths every year in 10,000, destroy 64 in 10,000 of the Household Caralry, 66 in 10,000 of the Dragoon Guards and Dragoons, 89 in 10,000 of the Infantry of the Line, and 125 in 10,000 of the Foot Guards; and, when compared with other causes of death, these diseases are found to prove fatal in the proportion of about 54 per cent. in the Cavalry; 
of about $57^{\circ}$ per cent. in the Infantry of the Line, and of about 68 per cent. in the Foot Guards.

I may state in passing (I shall speak more at length on this point presently) that there is no doubt whatever that over-crowding is one of the most efficient causes of consumption; so that, if fever may be looked upon as the acute disease of crourds, consumption may be considered as their chronic malady. But the dependence of pulmonary consumption on over-crowding will be best discussed when I have asked and answered this question,-Are our barracks and military hospitals over-crowded? I will give you the means of judging for yourselves by stating a few facts relating to different periods of time. You have the Tables before you*-Tables which I have been at some pains to compile from the Returns published in the Appendix to the Report of the Commission-but I will read to you the general results.

I.et me first remind you again of the statements made in the House of Commons in 1847, by Sir de Lacy Evans and Colonel Lindsay, respecting the disgraceful want of space in some of our London barracks. These statements produced just enough effect upon the House to cause some Member or other to move for a Return of the cubic space in barracks throughout the country, which Return was printed in 1848, and supplied us with some facts worthy of a place at the side of those I have just referred to. This Return gives us examples of barrack-rooms in London used as dormitories and day-rooms by grown-up men (tall, strapping fellows, as many of our soldiers are), affording to each man only 397 cubic fcet of air to breathe, and worse cases still of $390,376,370,363,331$, and in the case of a temporary barrack at Kensington 285 cubit fect. In other parts of the United Kingdom the figures are still more unsatisfactory-still more disreputable. At Chatham and Upnor (I am still speaking of 1847) the Infantry were put upon the miserably short allowance of 220 cubic feet of air per wan (the maximum at Chatham was only 350); the Cavalry at Maidstone were doomed to 174 cubic feet; and the soldiers in Dover Castle must have been rotting, like sheep in the marshes, in a filthy atmosphere, measured out at the starvation rate of 147 cubic feet 
per man. Scotland was favoured with a minimum supply of 240 ; but Ireland presented a series of low averages, falling from 228 at Portumna and Nallow to 158 at Rutland.

The average space in the 11 Returns from London was 400 cubic feet; 143 Returns from Ireland yielded the same average; 34 from Scotland gave an average of 432 ; and 155 from England, 447 cubic feet. This was in the year 1847; and who, with these facts before him, can be surprised at the ontbreak of cholera in our London barracks in 1849? Who can be surprised at the prevalence of ferer and consumption anong our soldiers?

Since $\mathbf{1 8 4 7}$, as many as $\mathbf{1 4 2}$ new barracks have been erected, of which 132 are in Fngland; and we have another Return showing the cubic space in the barrack-rooms of these new buildings. Of the whole number, two aftorded a space of less than 300 cubic feet, four others a space of between 300 and 350 , scventeen others a space of from 350 to 400 , and fifty-nine barracks a space of from 400 to 500 cubic fect; in sixty barracks only was the space of 500 cubic fect per man excceded. The barrack-rooms, properly so called, do not yield an average space of more than 550 cubic feet; and instances are given of such contracted spaces as $308,306,303$, and even 280 and 270 cubic fect.

Let us now come to the present time, and see what this Report has to say upon the subject. We are first told that the new barracks erected since 1855, when the Barrack Committec held its sittings, afford very superior accommodation to those previously built, but that no important steps hare been taken towards supplying the deficiencies of the older buildings; that some of the most serious evils remain still unremedied; that the dormitories or barrack-rooms are very confined; and that, in a majority of cases, oven the minimum cubic space allowed to each soldier by regulation is not attained, the deficicncy in a number of barracks amounting to one-third and in some instances to more than one-half of the space allotted by regulation.

And now mark the contrast afforded by the Scotch pauper and the British soldiel. We have it on the authority of Sir John $M^{c}$ Neill, that the pauper in the Scotch workhouses is allowed 480 cubic feet per bed, and that this minimum is not only rigidly 
insisted upon, but that, the houses being scarcely ever full, it is practically much exceeded; and, moreover, that the pauper is never in his dormitory during the day. In the soldier's barrack, on the other hand, it often happens that cven the regulated space of one foot between the beds (I an quoting the very words of the Report, one foot betucen the beds!) is practically unattained. The Report goes on to say that the barrack-rooms very seldom have windows at the opposite sides or cuds of the rooms; that where ventilators exist they are frequently stopped by the men themselves (of course they are, for you cannot safely practise ventilation in these narrow spaces); that barrack-rooms are occasionally found in the basement of the building, approached by descending steps from the natural surface level-the tops of the windows, which open on one side only of the rooms, being little, if at all, above such surface level-and that in low rooms thus situated a number of men may be found lodged in beds so closely ranged that the side of one touches the side of the other. The result is, that the soldier sleeps in a feetid and unwholesome atmosphere. This, let me remind you, is just such a state of things as John Ifoward, to his surprise and sorrow, found prevailing in our prisons in the year 1774: just such a state of things as the I.egislature of that day thought too bad even for the worst of their inmates. But perhaps you will attribute this narrowness of space in our barracks, old and new, to the ignorance of the arehitects or the perverseness of commanding officers in putting more men into the rooms than they were intended to hold. No such thing. The persons immediately concerned, if they were not obeying the letter, were acting in the spirit, of the instructions they received, as you will see when I tell you that the "Orders and Regulations for the Guidanee of the Corps of Royal Engincers and Royal Sappers and Niners at Home and Abroad, revised, by order of the Master-General and Board of Ordnance, to 1st January, 1851," prescribed only from 400 to 500 cubic feet per man in temperate climates, and from 180 (the Scotch pauper's allowance at home) to 600 in tropical climates, with a proviso that in general the maximum space was to be allowed, and for single bedsteads. The Report of the Commissioners recommends 600 cubic VOL. II. 
feet to ench man. This, you will say, is an extremely moderate allowance; and I hope that the nation which does not think 480 cubic feet too much for a Sçotch pauper, and does not grudge $\mathbf{9 0 0}$ cubic feet, with ventilation superadded, to the prisoner at Pentonville, will be able to afford this moderate supply of 600 cubic feet to the English soldier.

Now, by way of contrast, let us see how benevolent persons, mored by motives of economy, and anxious to make a profit by providing decent accommodation for the poorest classes, behave towards their clients. In the year 1848, the model lodging-house in George Street, St. Giles's, was opened with great state and ceremony by His Rojal Highness the Prince Consort, who presided at a public meeting held at Freemasons' Tavern. I do not know whether our Chairman was present, but many distinguished persons were there, and all the world heard of $i t$, and seemed to take an interest in it. This model lodging-house was intended to supply the conveniences and comforts of life to the poorest class of the people for the very low charge of four pence a night. For this small sum of money the Society for Improring the Condition of the Working Classes contrived to furnish their lodgers with many comforts an? luxuries. There was a separate coffee-room, with a good fire and constant supply of hot water; each lodger had his orn sleeping room separated from his neighlours; water and gas were laid on; there was a good kitchen, with facilities for boiling, roasting, baking, and frying; a pantry with a separate cupboard for his provisions; larntories, a cleaning-room, hot and cold baths, and other conveniences which I cannot stop to specifj. Now, what cubic space did these gentlemen think it necessary that an honest working man should have to breathe? Why, 542 cubic feet. That is what they gave him. I have rorked out the calculation, and it comes to that. So that these excellent people, catering for the very poorest class of labouring men, having an anxions regard to economy, and wishing to establish an example of profitable inrestment, provide dormitories, to be used only as such, with $\mathbf{5 4 2}$ cubic feet of air to each inmate, while three years later the Board of Ordnance were not ashamed of prescribing from 400 to 500 cubic 
fect of air as a fit and proper allowance for the British soldier in barrack-rooms destined to the two-fold use of dormitories and dayrooms.

One word as to the accommodation for married soldiers. It appears from a Return presented to the House of Commons in 1857, that out of 251 stations there were only 20 in which any scparate accommodation was provided for married soldiers. When such separate accommodation is provided, it seems to be on a par with the provision made for the single soldier in barrack-rooms. At Dover, we are told that it consists of rooms 12 fect 7 inches long by $\mathbf{7}$ feet broad and $\mathbf{7}$ feet high, affording for a whole family a cubical space of little more than 600 feet. At Woolwich, a staff-sergeant with his wife and five children sleep and live in one room, in which all the household labours are performed. In the casemates of Chatham the overcrowding is grenter, and the decencies of life are still less regarded.

From barracks let us turn to hospitals, and see what the theory and practice of the Board of Ordnance was in respect of these important buildings. I will begin, as before, with the year 1847 . At that time no less than fifteen wards of military hospitals, in different parts of the country, gave an average supply to their sick inmates of less than 400 cnbic feet of air; and the Return contains figures falling by easy gradations from 392 to $385,365,357,348$, $346,344,325,324,286,204,256,243,236$, and 213 . The mean of 265 avernges, taken in every part of the United Kingdom, is only 643 cubic feet per patient. Now the least average space per patient in London hospitals, as appears from a recent Return obtained by Dr. Balfour, the Secretary to the Commission, is 800 cubic feet; the least from any county hospital, 653 cubic feet; the least from any Naral hospital, 752 fect; but the least cubic space allotted to a patient in any Military hospital is 400 feet, or precisely half the minimum space in any metropolitan hospital. This small figure of 400 cubic feet occurs twice in the 46 Military Returns, and in no less than 19 other instances the cubical space per patient falls short of the minimum prescribed by the Board of Orduance in 1851 . The mean results of all the average measurements are equally unsntisfactory; for, while the London hospitals 
give a numerical average of 1,472 cubic feet, the provincial hospitals of 1,075 cubic feet, and the Naval and Mrarine hospitals of 1,014 cubic feet, the Military hospitals afford to their patients only 658 cubic feet.

I think I have now proved to you conclnsively that there is overcrowding in our barracks, that there is over-crowding in the rooms of married soldiers, and that there is over-crowding in our Military hospitals.

Now as to the effects of this over-crowding-as to the consequences of having so little air to breathe. I will begin with some extreme cases, the particulars of which are given in a few words in the Table before you. You will please to understand that the height of the parallelograms, on the left hand side of the Table, is in every case supposed to be 10 feet, and the depth 1 foot, so that the areas correspond rery closely with the cubic spaces themselves, and present them very clearly to the cye. A second column of the table specifies the scenes of the orer-crowding, and a third column the result of it. I begin with the tragedy in the Black Hole at Calcuttil-a place that has a special interest at this moment, when our minds are so much engrossed with painful events in India. Of 146 persons slut up in that narrow space, with only about 20 cubic fest of air per head, one-third died in less than three hours, and only 23 were left alive at the end of ten hours. The greater number of this small band of survivors were scized with a putrid fever and died. The next case of over-crowding comprised in the 'Table is that of Marlborough IIouse, Peckham, the union workhouse of the City of London, in which the male paupers of the city were famed out, from the formation of the union in 1837 till a comparatively recent period. This municipal Black Hole was a sort of shed, 7 feet pitch in the centre, and 2 feet at the sides where the men's heads rested at night; and its dimensions were such as to give to each wretched inmate from 30 to 60 cubic feet of air to breathe. At its fullest, it is said to have held from 90 to 100 menl. $\Lambda$ s the room was 33 feet 9 inches long, and 20 feet wide, it will be easy to calculate the space on the floor allotted to each man. As the number of inmates ranged from 50 to 100 , let us take it at 68 , and call the length of the place 34 feet. If the men were ranged 
Cubic feet.

20

- I

30

to

60
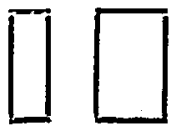

52

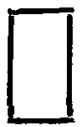

84

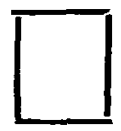

100

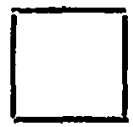

136

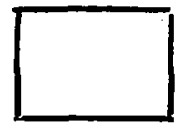

170

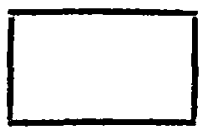

202

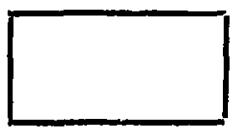

258

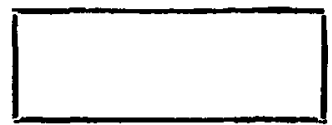

\section{EFFECTS OF OVER-CROWDING.}

Black IIole, Calcutta .... $\begin{gathered}\text { Of } 146 \text { persons, } 23 \text { left } \\ \text { alive after } 10 \text { hours. } \\ \text { Fatal ferer in survirors. }\end{gathered}$

Marlborough Iouse, Peck-
ham, City of London
Union Worlhouse .... $\begin{aligned} & \text { Londor patients sent to } \\ & \text { in one year; One-fifth } \\ & \text { of total in hospital. }\end{aligned}$

Church Lane, St. Giles'.. $\begin{aligned} & \text { Great mortality among } \\ & \text { children and adults. } \\ & \text { Fever. Cholera. }\end{aligned}$

Village in Dorsetshire .... Fatal ferer.

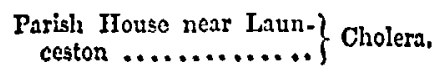

Drouet's Establishment for
Pauper Children at
170 deaths from Cholera
in three weeks. Tooting, January, 1849 in three weeks.

Cambridge Town Bride-
well, $1774 \ldots \ldots \ldots \ldots$ Gal ferer.

Printing Office ......... Consumption.

Christchurch Workhouse,
Children's Sick Ward, Gangreno of the mouth.

Prison allowance 1000 cubic fect.

* In one ward 132 cubie feet, 288 cubio feet is the arerage of a number of wards. 
in two rows, each man must have had exactly 2 feet, or about the width of his own shoulders, to lie ou ! Close packing this. Well! What was the result?. The place was a perfect fever factory. It sent 180 fever patients to the London Hospital in one year, being more than one-fifth part of the total admissions. The ratepayers, of course, had a pretty bill to pay for all this-a much larger one than they imagined, or I know how to calculate.

I now come to a case of over-crowding of which a gentleman whom I see present (Mr. Neison) is cognizant, for he, with Colonel Sykes and myself, formed a small committee appointed by the Council of the Statistical Society, to examine the scene of it. I speak of Church Lane, the solitary survivor of the once notorious Rookery of St. Giles's. In this miscrable lane we found a number of rooms so densely crowded, that the cubic space per person ranged from 93 down to 52 feet. The sickness and mortality prevailing among these wretched people was frightful. We compared the mortality with that prevailing at Islington, and found it double for the first year of life, and nearly sevenfold for the second year. Iike Mariborough House, too, the houses of this lane were a perfect fever factory; for in a period of less than seven months.139 persons living in Church Lame were under trentment by the workhouse staff, of whom 88 were ill of fever. Onc house alone contributed 22 cases of sickness and 14 of fever. The cholera of 1849 also found out this fifthy lane, as it did the barracks of our soldiers. In little more than one month the pestilence carried off 29 yersous, of whom 17 were inmates of the louses which our committce inspeeted. This was at the rate of 6 in the 100, while the model lodging-house in George Street, within a stone's throw of Church Lane, with a population also of 100, lost only one man by that disease, and he a man of very advanced age. In amother model lodging-house near old St. Pancras Cluurch, there was no death from cholera in a mixed population of 500 men, women, and clildren.

The scene of my next case of over-crowding was a house in a village of Dorsutshire, described some years since by the correspondent of the Morning Chronicle. The cubic space allotted to each inmate of the cottage at night was 84 feet, and fatal fever was the result, reducing the family fron twelve to eight. 
I now come to speak of larger spaces. Before the erection of the union workhouses, the poor were accommodated in poor-houses or parish-houses, some of which have since been let out for small weekly sums to persons just on the vorge of pauperism. In one of these parish-houscs near Launceston, the space amounted to 100 cubic feet for ench inmate, and in one stch house the cholera carried of five victims and dispersed the remainder.

My next example of orer-crowding is Drouet's establishment for pauper children at 'Tooting. The space in the durmitories alforded to each child 136 cubic fect, and that one establishment contributed to the death-roll $1 \% 0$ deaths frum cholera in three weeks, in addition to 15 deaths in the workhouses to which the children were removed, and 8 deaths by similar discases, making a total mortality of 170 .

I have been able to extract from Howard's work on prisons one instance (namely, the 'lown Bridewell at Cambridge) in which I could calculate the cubic space; it amounted to 170 feet: gaol fever attacked the immates, closed the establishment, and proved fatal to three out of the serenteen women confined therc.

I have myself examined a number of printing-offices in which the space is very linited, and in one of them $I$ found the arerage space to be 202 cubic feet. Consumption was unusually prevalent tlierc. I have a very distinet recollection of at still worse office than this, in which consumption was eo prevalent that it created the same alarm that a contagious fever would have done.

My last case of over-crowding forms one of the worst instances of totally inadequate space recorded by the Poor Law Commissioners in 1848. The cholera was expected, and the Poor Law authorities wanted to know what accommodation the London workhouses afforded for the reception of patients suffering from that disease. One of the worst of many bad eases recorded on that occasion was the case of the Christ Church Workhouse. Its sick wards actually yielded an arerage of 288 cubic feet per patient; and one of the wards gare only 132 cubic fect for each immate. In this instance the prevalent disease was gangrene of the mouth, a very fatal and intractable malady. Some external nuisances contributed to this result, but the disease prevailed whatever the direction of the wind. Now, by way of contrast to these cases of over-crowding, 
I place, at the foot of the Table, the prison allowance of 1,000 cubic feet. It is usually set down at this figure, but we have it distinctly given in evidence beford Mr. Sidney Herbert's Commission by Colonel Jebb, that in Pentonville prison the allowance is 900 cubic feet per prisoner, plus ventilation. In the cases I have just commented on, and in the barracks of the soldier, the narrow spaces are either minus ventilation, or they are accompanied by attempts at ventilation which the narrowness of the space renders either abortire, or, from the severity of the drafts, highly dangerous.

The cases which I hare just been describing are intended to show the baneful consequences of over-crowding carried to an extreme. But I think it fair to infer that very disastrous consequences may, and do, result from much less degrees of overcrowding than these-from such over-crowding as exists in all our barracks at the present moment. But perhaps you will call for some clear case of over-crowding among soldiers, followed by some such consequences as I lave been describing. Fortunately I am prepared with such a case, on the high authority of MI. Boudin, a French sanitary reformer well known in this country.

"During the period from 1843 to 1847 inclusive, I ascertained," he says, "the existence every year, at the Military Hospital of Versailles, of a fatal cpidemic of typhoid fever, raging about the month of October among the sick who came to me from the garrison of St. Cloud. The epidemic had this remarkable feature, that it broke out every year eight days after the arrival of the ex-King, and that it disappeared immediately after his departure from St. Cloud, without ever attacking either the civil population or the officers, or even the sous-officiers, though these latter inhabited the same barracks as the corporals and soldiers. The following facts give the key to this pathological enigma. The garrison of St. Clond in ordinary times consisted of from $\mathbf{4 0 0}$ to $500 \mathrm{men}$, and had scarcely any sick, but on the arrival of the King the garrison was increased to 1200 . The men were then crowded into a narrow and ill-ventilated room, whilst the sous-officiers, better fed and less harassed with duty, had always at least one room for two men." This is a striking and an interesting illustration of the efficacy of over-crowding in producing fever. 
Now, let me ask your attention to a fact or two with regard to consumption. I want to show you that this disease, too, may be brought on by over-crowding. $\Lambda$ gent]eman now present, (Dr. Neill Arnott, ) in his evidence before the Health of Towns Commission, tells the following instructive story about certain monkeys in tho Zoological Gardens. "A new house," he says, "was built to receive the monkeys, and no expense was spared which, in the opinion of those entrusted with the management, could ensure to those natives of a warmer climate all attainable comfort and safety. Unhappily, however, it was believed that the object would be best secured by making the new room nearly what an English gentleman's diauringroom is. For warming it, two ordinary drawing-room grates were put in as close to the floor as possible, and with low chimney openings, that the heated air in the room should not escape by the chimney, while the windows and other openings in the walls above were made as close as possible. Some additional warm air was admitted through openings in the floor from around hot-water pipes placed beneath it. For ventilation in cold weather, openings wero made in the skirting of the room close to the floor, with the erroneous idea that the carbonic acid produced in the respiration of the animals, become heavier than the other air in the room, would separate from this and cscape below. When all this was done, about sixty healthy monkeys, many of which had alrealy borne severnl winters in England, were put into the room. A month afterwards more than fifty of them were dead, and the few remaining ones were dying. This room, open only below, was as trnly an extinguisher to the living monkeys, as an inverted coffee-cup held over and around the flame of a candle is an extinguisher of the candle. Not only the warmth from the fires, and the warm air that was allowed to enter by the openings in the floor, but the hot breath and all the impure exhalations from the bodics of the monkeys, ascended first to the upper part of the room to be completely incorporated with the atmosphere there, and by no possibility could escape, except as part of that impure atmosphere, gradually passing away by the chimueys and the openings in the skirting. Therefore, from the time the monkeys went into the room till they died, they could not have had a single breath of fresh air. 
It was only necessury to open, in the winter, part of the ventilating apertures near the ceiling; which had been prepared for the summer, and the room became at once salubrious." I have only to add to this story the fuct that the disease of which these animals died was consumption, to convince you of the fatal efficacy of foul air in producing that disease. The general accuracy of this story was confimed by n collengue of my own at ling's College, (Professur Rymer Jones,) who informed me that similar results followed similar treatment in other animals, with this addition, that, when a more liberal supply of air was afforded them, they manifested a somewhat inconvenient increase of appetite. I have no doubt that the same result will happen when our soldiers have a larger supply of air; but I trust we shall be able to afford the increased outlay for food, and shall not grudge it.

You will perthaps object to this monkey-case, and to other analogous facts relating to animals, that they are not quite applicable to the Luman subject. If so, I am lrappy to say that I can satisfy your minds. I am uble to prove to demonstration, that, if you do put men into such narrow spaces is our soldiers are condemned to live and sleep in, they will ccrtainly dic of consumption. Several years ago, being struck with the high rate of mortality prevailing among letter-press printers, I went carefully through a great number of printing-offices and made the inquiries I am about to describe. I may premise that the compositors, who set up the types, use very little excrtion in their employment, and are often pent up in very marrow spaces, brenthing a heated and impure atmosplere. The great majority of the men to whom my inquiries were addressed were compositors-a few only were pressmen. I measured the aren of the several rooms with the utmost care, and calculated the cubic space to each inmate; and I put a few plain questions to each man-the same questious in each case. I inquired of each man particularly whether he had ever spit blood, and to what other diseases he was subject. The object of this first question will be very apparent to a medical 1man. Spitting of blood is one of those symptoms which is so common in consumption, and so rare in other diseases, that if we are dealing with a considerable number of persous, and comparing one large group with another, this symptom 
of spitting of blood may stand for consumption without leading to any scrious error. Now, the resplts of these careful inquiries are TABLE'X.

Table shoming the Connegtion of Puldonary Consumption mith Over-Grolrding.

\begin{tabular}{|c|c|c|c|c|c|c|c|c|}
\hline & \multirow{2}{*}{ 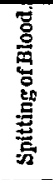 } & \multirow[b]{2}{*}{ 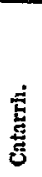 } & \multirow{2}{*}{ 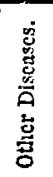 } & \multirow[b]{2}{*}{ 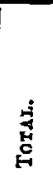 } & \multicolumn{4}{|c|}{ Per-Centage Proportion. } \\
\hline & & & & & 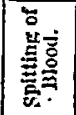 & 突 & 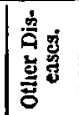 & 总 \\
\hline $\left.\begin{array}{l}104 \text { men having less than } 500 \text { \} } \\
\text { cubic feet of air to breathe. } \\
115 \text { men having from } 500 \text { to } 600 \\
\text { cubic feet of air to breathe } \\
101 \text { men having more than } 600 \\
\text { cubic feet of air to breathe. }\end{array}\right\}$ & $\begin{array}{r}13 \\
5\end{array}$ & $\begin{array}{r}13 \\
4 \\
2\end{array}$ & $\begin{array}{l}18 \\
23 \\
15\end{array}$ & $\begin{array}{l}44 \\
32 \\
24\end{array}$ & $\begin{array}{r}12.50 \\
4.35 \\
3.96\end{array}$ & $\mid \begin{array}{r}12.50 \\
3 . \pm 8 \\
1.98\end{array}$ & $\mid \begin{array}{l}17 \cdot 31 \\
20 \cdot 00 \\
17 \cdot 82\end{array}$ & $\begin{array}{l}12 \cdot 31 \\
27 \cdot 52 \\
23 \cdot 76\end{array}$ \\
\hline
\end{tabular}

cmbodied in the Table before you; and I look upon them as peculiarly important at this moment, as they seem to form the very key-stone to the arch built up by Mr. Sidney IIerbert's Commission. I cncountered $10 \pm$ men unfortunate enough to have less than 500 cubic fuet of air to brcathe, the average, of course, being much less than that. Now, these men had spit blood at the rate of $12 \frac{1}{2}$ in erery hundred; and the same number, 121, said that they were constantly suffering from what they call colds. I found another body of 115 men who had from 500 to 600 cubic feet of air to breathe, and, therefore, very much more than the first group, of whom some had, as you have scen, as little as 202 cuibic feet of air to breathe; and these 115 men, instead of suffering to the extent of $12 \frac{1}{2}$ in the 100 from spitting of blood, stufered at the rate of little more that 4 per cent., while the liability to colds fell in nearly the same proportion. Lastly, I found a third group of 101 men who had more than 600 cubic feet of air to breathe, and their liability to consumption was still further reduced to a little less than 4 per cent, and their liability to colds to a little less than 2 per cent. If I had more time, I could give you two or three other comparisons of tho same kind, leading to the same result.

I do not think that there is any fallacy about these facts. I can 
answer for it that I did not make these observations and calculations with the most remote desire to arrive at any particular result, but only to ascertain the truth. I speak therefore with the utmost confidence when I say, that if you will limit men in the quantity of air that they have to breathe, and bring it down to such low averages as you have in your barracks, and, especially, if you do not provide sufficient exercise for them, you will inevitably have a great deal of consumption. I may mention, by-the-bye, that the fine dust from the sanded floors of the barrack-rooms, and the dust of the pipe-clay from the belts, gloves, and white jackets of the Guarls, are not very farourable to men with weak lungs.

I have thus demonstrated to my own satisfaction, and I trust to yours also, three leading facts; First, that a very high rate of mortality prevails among our soldiers generally, but especially our foot soldiers; Secondly, that our barracks and hospitals are greatly over-crowded; and, Thirdly, that this over-crowding issues in fever, cholera, and such like diseases on the one hand, and diseases of the chest, but especially consumption, on the other.

It is now time that I should think of bringing this Jecture to a close. I have" given you a mere outline of a very great and very grave subject. I have displayed the facts of the case as clearly as I could, and $I$ have to the best of my beliuf explained the causes. I would again and again insist on the two great evils of over-crowding of barracks and hospitals, and the want, considering the class of persons with whom we have to deal, of sufficient exercise. I do not expect-I have no right to expect-that all those whom $I$ have now the pleasure of addressing should agree with me as to the causes which give rise to this high mortality of our soldiers. The only agreement that $I$ seek for is a hearty determination to cooperate, according to our respective opportmities, to bring it about that the state of things described in this Report shall exist no longer.

But if there is any one now present who attaches special importance to one of the alleged causes of the soldier's mortality rather than another, let that man exert himself to get that evil remedied. If any one thinks that the figures which represent that mortality are not strictly accurate, let him do all he can to obtain weekly 
retums of the deaths and attacks of sickness cccurring anong all our troops in the United Kingdom; and let those weekly returns be compared minutely and carefully with the, deaths among the civil population of the soldiers' ages, that we may know the truth, and know it in such good time as to be able to act upon it; so that, whenever any military station is found to be subject to an unusual mortality, some skilful person may be despatched to investigate the cause of it, and, within certain necessary limits of expense, to rectify it. Let us also have similar returns from foreign stations at as short intervals of time as possible.

If there is any one here who objects to the soldier's clothing as a cause of disense, let hin exert himself to bring about a reform in that respect. If any man thinks that the food of the soldier is monotonous, and the means of cooking it insuficient, let him do all he can to promote a more rational state of things. Do not let it be said that, whereas the poor in our lodging-houses can cook their food as they please, the British soldier is condemned (so far as the barrack-kitehens are concerned) to a nauseous monotony of diet. But to come to more important matters. If any one thinks that night-duty is the cause of the mortality of the soldier (and with the facts I have brought forward respecting the Fire Brigade and the Police staring lim in the face it is impossible to allege that nightduty as such is fatal to life), let him find out what unnecessary accompaniments there are which make that duty as performed by the soldier injurious, and then let him exert himself to set that matter to rights.

If any one thinks with me, that the mortality among the Infantry. is due in no inconsiderable degree to want of proper exercise, let him agitate for improved drills. Let every soldier be taught the sword exercise; or, if it scem inexpedient to increase his drills, let him be cncouraged to take every kind of manly excrcise: Iet every barrack have a covered space, to which the soldier may retreat in bad weather, and find the means of indnloing in athletic sports.

In country barracks a cricket-ground ought to be a sine qud non, and I do not see why some modified system of allotments should not be carried out, so that the soldier might lave the whole- 
some labour of the farm or garden, with the stimulus of profit to induce him to work. If we were wise, and dared to raise ourselves above routine and prejudice in this matter, we should teep the soldier as much as possible in the condition of the agricultural labourer, whose duration of life I have shown to be so favourable.

Then, with regard to dissipation and intempernnce-if it be true that the soldier is a dissipated and intemperate man, there can be no doubt that his health will suffer most seriously from those causes. Let him therefore who thinks so, do his very utmost to create and bring into play the largest possible amount of counter-attractions to the temptations to dissipation and intemperance which are known to assail the soldier.

But if any one thinks, as I do, that the first and greatest cause of the high mortality of the soldier is the wholly insufficient space alloted to him in barracks and in hospitals, then let him give his whole heart and soul to this rital matter. Juet us hear no more about the ventilation of the present buildings; let us have no pottering experiments to bring fresh nir into these narrow spaces. You cannot safely and efliciently ventilate them. But let us do all we can, individually and collectively, to cause the Legislature of this country to make a large and liberal vote of money. It is a mockery to attempt to do anything without it. Wre want the money from the House of Commons; and, if any man thinks that the money is not to be had, it is for him and for us to take those steps by which the House of Commons may be hrought to a sense of its duty.

Lastly. If there is any man here so entangled in the meshes of red tape that he cannot stir hinself-so tightly bound in the fetters of routine that he camot move till released by precedents, I will give him precedents. I tell him to look at the case of the sailor. For three quarters of a century, as I have already reminded you, the condition of the sailor has bcen in constant course of improvement. His case ought to be precedent enough; but, if you want a case of such convincing cogency that no man of common humanity and common sense will dare to gainsay it, I will give you the case of the prisoner.

Three quarters of a century ago, also, John Howard brought 
before a Committee of the whole Ilouse of Commons (not a small Comnitte like that whose Report we have been considering, but a Committee of the whole House) facts relating to the condition of the prisoner, bearing, many of then, a much closer resemblance than it is pleasant to think of to the barrack rerelations of this Report; and the House not only gave him a vote of thanks, but that very year passed two Acts which liberated the poor prisoner (for he was often a debtor merely and not a culprit) from the evils under which he was suffering-from illegal fees on the one hand, and from the perils of the gaol-ferer on the other.

But, if any man is sceptical as to the reality of sanitary science and the power given to us of presgrving health by simple menns, I would ask him to go back to that same period (three quarters of a century ago), when Captain Cook demonstrated, by the example of his voyages round the world, that the sailor's life might be preserred from scurvy, and the other fatal diseases which afticted him. I would remind him how trimmphantly Joln IIoward proved that gaol-fever might be rooted out by the same means which we are now invited to apply to our barracks; and how Jenner proved to demoustration that, if men would but consent to use the boou which Providence lad enabled him to place at their disposal, the smallpox might be driven from the face of the earth. Such cases as these ought to satisfy the most sturdy stickler for precedents. Three such cases, occurring as they did in the same quarter of a century of our eventful history, would be cnough in themselves to constitute the glory of any mation but this. I say that you have precedents enough. 'The sanitary history of the army itself abounds in them. But, if we must lave another precedeut, we shall find it ready to our hands in the contrast afforded in the Crimea between the frightful effects of negligence, carelessness, and incompetency in the management of affairs, and the happy state of things brought about by their opposites.

And now I shall take the liberty of addressing you in the language of entreaty. I do besecch you, by the glorious military history of England; by all that our soldiers have donc and suffered for us in times past; by the triumpls and trials of the Crimea and of India;-I entreat you by your recollections of the heights of 
Alma and Inkerman, of the plain of Balnklava, of the trenches of Sebastopol; by the siege of Delhi; by the defence and relief of Lucknow-but, above all, by the recollection of that scene on the deck of the burning "Sarah Sands"-and, above and beyond all, by that sublime scene on the deck of the sinking "Birkenhead," before which the noblest deeds of ancient heroism sink into insignificance, and to which the glorious annals of Greece and Rome afford no parallel,-I entreat you not to leave this place with hearts untouched, and resolutions half formed; $-I$ beseech you to join hand and heart in one great effort to obtain justice for the British soldier!

For myself, I must say that I did not come here simply to state ficts and figures, and offer explanations of them. I did not come here merely to solve a difficult problem in sanitary science. I cannot consent to view those figures as mncre lifeless sunus in arithmetic. I know that every unit represents a scene of individual suffering-a death by fever, cholera, or consumption-which it was our duty to have rendered unnecessary. I came here for a very different purpose. Just as men with their hearts full of private sorrow seek a solitude wherein to weep, so $I$, with a great public grief pressing heavily upon me, have chosen this time and place to give vent to my feelings of surprise, sorrow, and indignation, that in the middle of this ninetcentl century, in this year 1858, such a Report as the one which now lies upon your table should have been possible. In this matter, if in no other, I hare obeyed the dictates of my conscience-Liberavi animam mean. I have paid the first instalment of my debt of gratitude to the noblest and bravest army that ever rallied round the standards of a careless, indifferent, and too often ungrateful, nation. 